\title{
The excavation of Gua Siti Nafisah, Kecamatan Weda, south-central Halmahera
}

\author{
Peter Bellwood, Gunadi Nitihaminoto, Gunadi Kusnowihardjo, \\ and Agus Waluyo
}

The northern end of the southern arm of Halmahera is about $18 \mathrm{~km}$ wide, rugged and uninhabited in its interior. It consists mainly of late Oligocene to early Pliocene sedimentary rocks (Hall et al. 1988). In 1991, a dirt road crossed from Payahe in the west to Weda in the east, travelled by hired four-wheel drive vehicles. Weda itself, the administrative town of Kecamatan Weda, lies in a protected bay towards the northeastern limit of the arm.

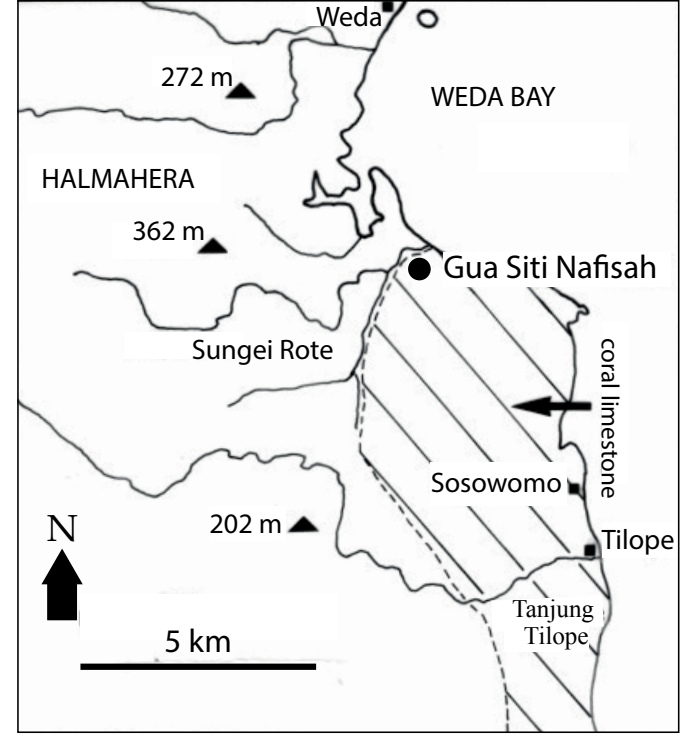

Figure 4.1 Map of the Weda region and location of Gua Siti Nafisah.

The diagonally shaded area is limestone.

Source: Peter Bellwood.
The cave of Siti Nafisah is located near an agricultural field hamlet called Nusliko, about $5.5 \mathrm{~km}$ south of Weda (Fig. 4.1). The cave lies on the northern side of a limestone promontory, about $120 \mathrm{~m}$ south of the Rote stream and about $70 \mathrm{~m}$ above the stream bank (and thus presumably about $75 \mathrm{~m}$ above sea level). This limestone promontory forms the northern limit of a broad belt of uplifted Quaternary coral limestone, about $20 \mathrm{~km}$ long and up to $6 \mathrm{~km}$ wide, that runs down the eastern coastline of the southern arm of Halmahera, through the large village of Tilope.

The cave is reached by a fairly steep rocky climb from the plantations that line the banks of the Rote stream. The promontory continues to rise above the cave to an ultimate height of just over $100 \mathrm{~m}$ above sea level. The story goes that the grandmother of one of our local assistants, Siraju Jalalo, once dreamt that she met an imaginary woman called Siti Nafisah in the cave-hence the name. The original name of the cave seems not to be known. 
The cave is of phreatic origin, clearly indicated by blind passages in the roof that can rise up to heights of $10 \mathrm{~m}$ above the cave floor. In most of the occupied area the cave has a roof height of only about $3 \mathrm{~m}$. It has an irregular shape, delineated in Figure 4.2, and the interior portions (inwards of Squares J10 and E12) have no traces of human occupation as far as can be observed. Prior to excavation a $1 \mathrm{~m}$ grid was laid out for survey purposes, and three areas were eventually excavated, denoted F5-F8, J10 and E12 on the plan. The preceramic shell midden appears to be concentrated at the front of the cave, in and around Squares F5-F8, whereas the inner Squares J10 and E12 were laid out over pottery-bearing midden deposits that were visible before excavation on the cave surface.

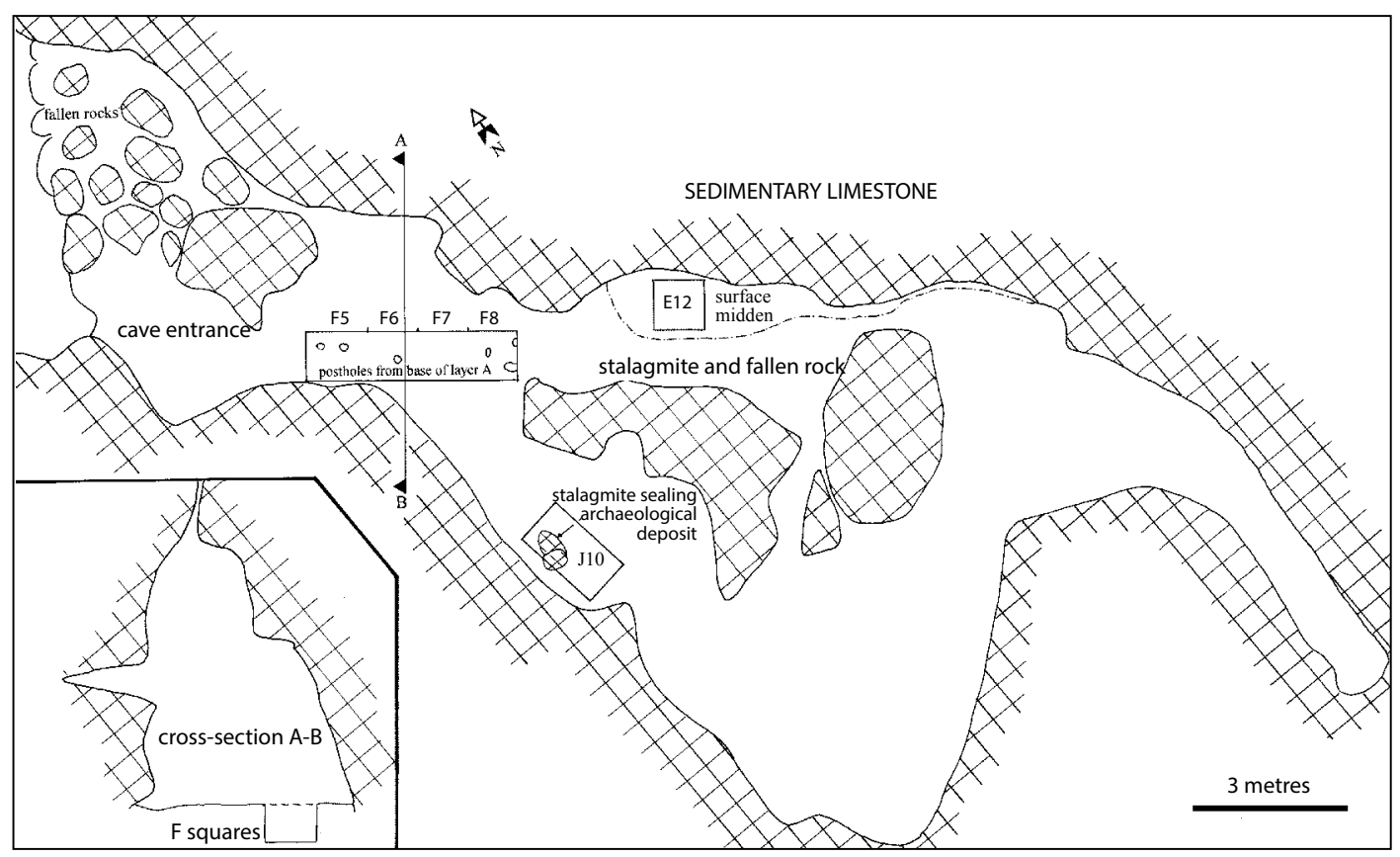

Figure 4.2 Gua Siti Nafisah: plan of the site.

Source: Peter Bellwood.

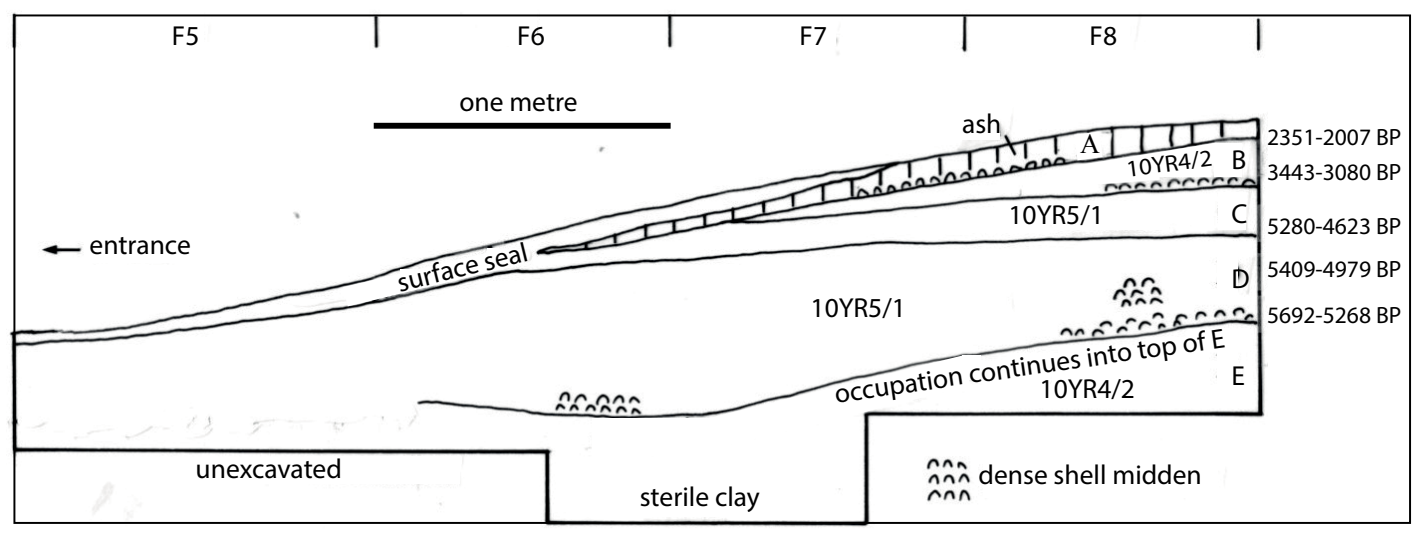

Figure 4.3 Gua Siti Nafisah: main section, Squares F5 to F8, east wall.

Details of C14 dates are listed in Table 1.1.

Source: Peter Bellwood. 
The main excavation, in Squares F5-F8, covered an area of 4.25 $1 \mathrm{~m}$. The stratigraphic section of this trench is shown in Figure 4.3, wherein it will be seen that five layers (denoted A to E) were differentiated in the inwards portion of the trench, in Squares F7 and F8. In Square F5, towards the mouth of the cave, virtually no layer differentiation was visible at all, the deposit here being shallow (over limestone bedrock) and rather heavily concreted in places. This may reflect erosion and the effects of drips close to the cave mouth. Square F6 was similarly without clear stratigraphic differentiation, and the side closest to the cave wall was heavily disturbed by a deep area of subsidence caused by solution of the limestone and consequent sinking of cultural materials into subterranean crevices. This disturbance extended back towards J10 as a shallow trench, visible on the cave floor before excavation. Square F7 had a rather clearer stratigraphy, which became very clear in Square F8, the innermost one.

The five layers in F7 and F8 were dug in spits between 4 and $10 \mathrm{~cm}$ thick-the increase to $10 \mathrm{~cm}$ in the lower Layers $\mathrm{D}$ and $\mathrm{E}$ occurred because of time pressures and because the deposits seemed sufficiently homogeneous to allow such spit thicknesses to be excavated without loss of information. In Table 4.1, the data presented are raw counts and weights only, not densities. The figures could be converted into densities by taking spit thickness into account, but this would be unlikely to change the observation that Layers A to D have fairly continuous distributions of cultural material, while Layer $\mathrm{E}$ represents the sterile natural deposit that has had cultural material mixed into its top. Layers $\mathrm{B}, \mathrm{C}$ and $\mathrm{D}$ have increasing percentages of fine fraction particles $(<0.063 \mathrm{~mm})$ with depth $(18,48$ and 56 per cent, respectively), but this might reflect no more than post-depositional sorting caused by water from roof drips moving clay downwards through the profile.

The layers will now be described in turn:

Layer A: This is basically an ash zone 5-7 cm thick, clearly differentiated from Layer B below. Layer A contains pottery, a stone adze and fairly dense shell midden, and is of the same general age as the pottery-bearing middens in areas J10 and E12 further inside the cave. It is dated by ANU 7785 on Anadara shell to 2351-2007 cal. BP.

Layer B: This layer is a dark greyish-brown soil with considerable quantities of shell midden, dated by ANU 7786 on Anadara shell to 3443-3080 cal. BP. On its upper surface there are sherds, a stone adze fragment, and a number of postholes dug in from Layer A that are plotted on Figure 4.2. Layer B itself, below its top surface, is undoubtedly preceramic.

Layer C is a grey soil with a similar midden concentration to Layer B, dated by ANU 7787 on Anadara shell to 5280-4623 cal. BP. It has a sharp interface with B, but grades downwards more gradually into D below.

Layer $\mathbf{D}$ is also grey in colour and continues the midden in a density similar to Layers B and C above. Layer $\mathrm{D}$ contained many volcanic oven stones, indicating that hot stone cooking had been carried out here, even though no pit was clearly visible during the excavation. Layer D is dated by ANU 7788 and 7789, both on Anadara shell, to 5692-4979 cal. BP. Layers C and D appear to be essentially continuous in deposition and texture.

Layer $\mathbf{E}$ is a dark greyish-brown soil, which appears to be the natural pre-human deposit within the cave. Bedrock rises through it in the southern side of F5 and in the southeastern corner of F8, but in F6-F7 it was dug to a depth of $110 \mathrm{~cm}$ below its upper surface without reaching bedrock. In hindsight, there may be an extremely small possibility that unexcavated cultural layers could lie below Layer E, which has cultural material only in its top $15 \mathrm{~cm}$, doubtless derived by downwards treading from Layer $\mathrm{D}$ above. Layer $\mathrm{E}$ also has a different grain size pattern from Layers B, C, and $\mathrm{D}$. While these three layers become finer downwards, Layer $\mathrm{E}$ is coarser, thus reversing the trend visible in the layers of human occupation. No dates were run for Layer E. 
As noted above, one of the problems encountered in this excavation was that the layers become quite invisible in Squares F5 and F6, so the following discussion of the distribution of cultural items through the stratigraphy is based mainly on Square F8, which yielded a sufficient density of material to give a reliable picture of the sequence. The question also arises of whether occupation of the site was continuous. All that can be stated here is that there is nothing in the distribution of artefacts (Table 4.1) to suggest any hiatus in occupation. During the preceramic phase the cave seems to have been occupied at a low intensity throughout, but fairly continuously. The dates are too close together to throw much light on this; all they can tell, when calibration is taken into account, is that the preceramic shell midden dates to between 5700 and $3000 \mathrm{BP}$, whereas the pottery and stone adze-bearing layer above, and the J10 pottery midden, date to less than 2400 years ago.

The Square J10, dug to a size of $1.8 \mathrm{x} 1 \mathrm{~m}$, was chosen for excavation around a large stalagmite that had formed on top of a shell-midden layer (indeed, the stalagmite had shells and potsherds embedded into its bottom). After removal of the stalagmite, a dense shell midden about 15$20 \mathrm{~cm}$ thick was revealed, with pottery throughout at a considerable density $(1575 \mathrm{gm}$ of pottery for the whole deposit in J10, as opposed to a total of only $230 \mathrm{gm}$ for the whole of the F5-F8 area). J10 also contained animal bones, importantly of Dorcopsis wallaby (but not bandicoot), suggesting that wallabies survived on Halmahera until the marine shell date for the J10 midden (ANU 7790: 1598-1268 cal. BP, see Fig. 4.4). Shell density in J10 was similar to that in the densest F5-F8 preceramic midden layers, and the same shellfish species were present.

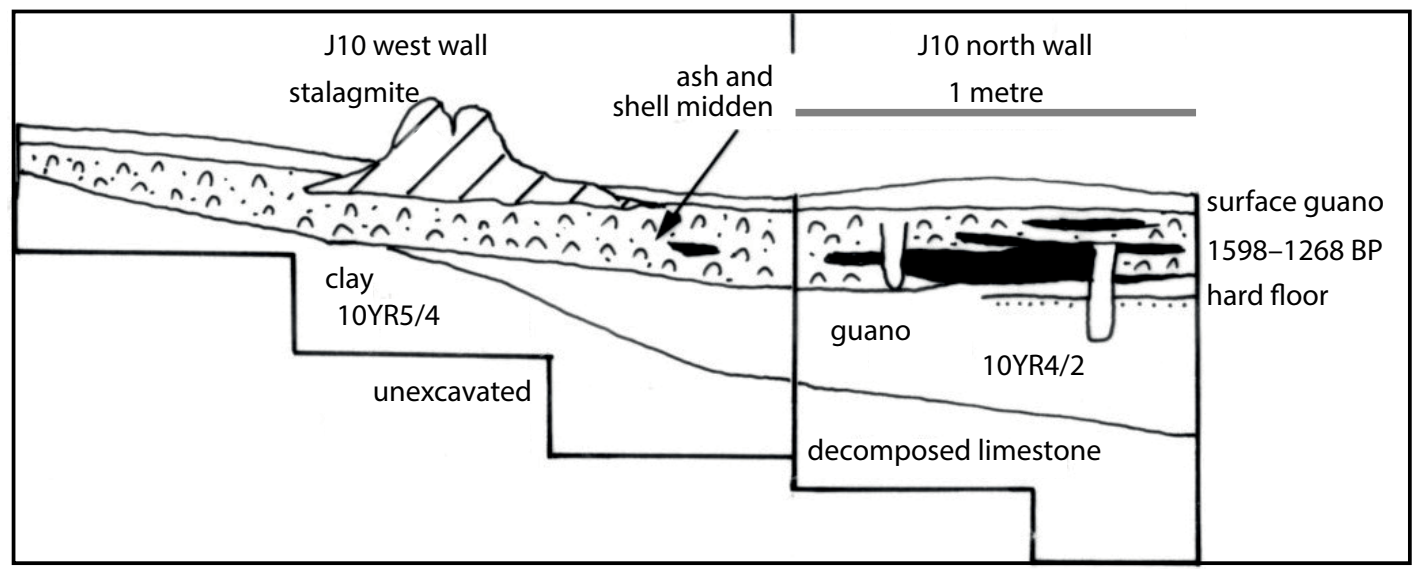

Figure 4.4 Gua Siti Nafisah: J10 section, west and north walls.

Black deposits are ash. Details of C14 dates are listed in Table 1.1.

Source: Peter Bellwood. 


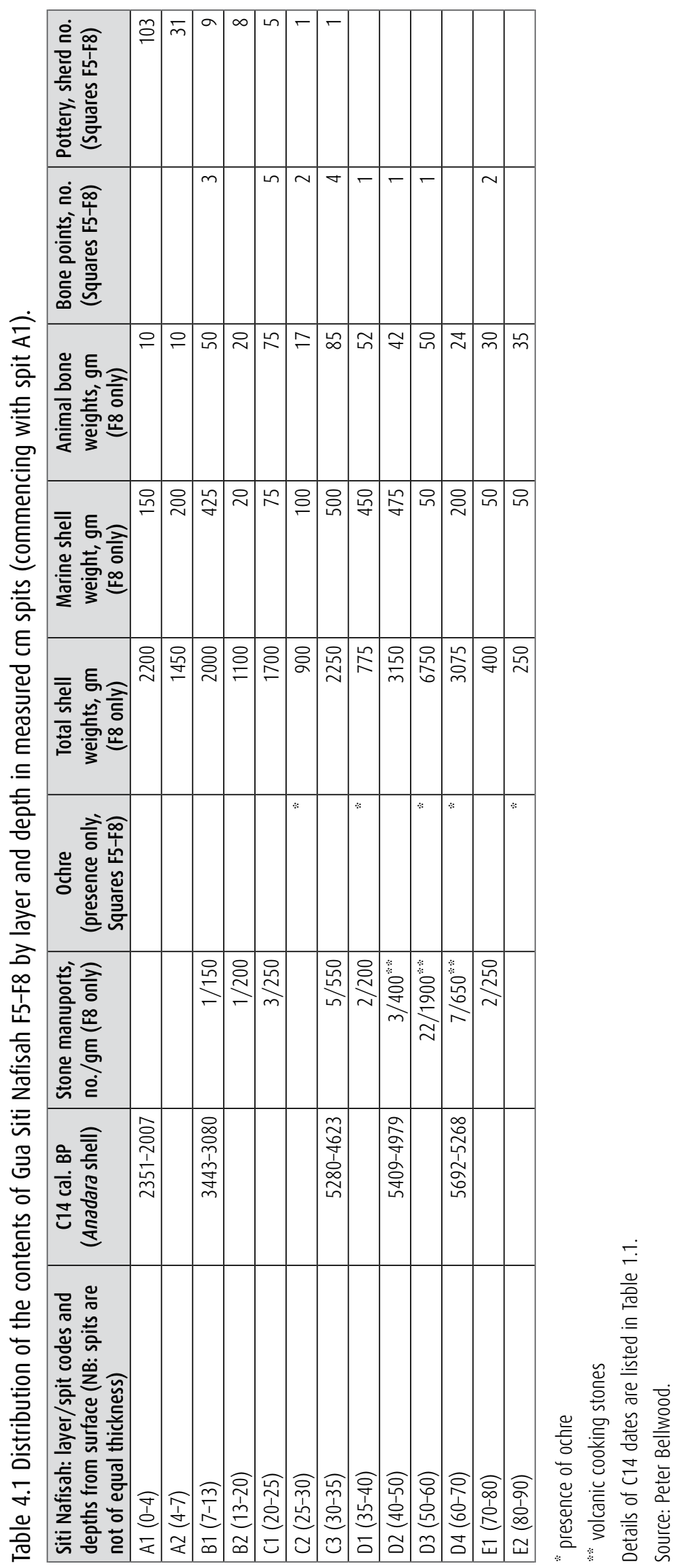


The J10 shell midden overlies a layer of dark greyish-brown bat guano, here fairly fresh and unweathered, but nevertheless alkaline, which in turn overlies a yellowish-brown clay, which grades down into rotten limestone and eventually the hard rock floor of the cave. Today, the cave has very active bat colonies in the interior and guano falls constantly. Indeed, the J10 guano layer is identical in colour and texture to the matrix of Layers A to E in Squares F5-F8, and to the soil matrix of the midden layer in J10, leaving little doubt how the bulk of the deposits in the cave originated.

In the northern part of J10 the guano contains, near its upper surface, a hard-stamped floor, which clearly represents human frequentation just prior to the deposition of the midden. An ash band on this floor, derived from a hearth (but without datable charcoal) yielded the stone adze butt drawn as Figure 8.4B. However, the suggestion made in an earlier report (Bellwood et al. 1993:30-31) that the stamped guano floor was preceramic requires modification, since a single potsherd from this ash layer was found during sieving of an ash sample to try to obtain datable charcoal (unsuccessfully) in the museum in Ternate in 1994. This adze is therefore of Neolithic and not preceramic origin.

Another $1 \mathrm{x} 1 \mathrm{~m}$ square was dug at E12 on the plan. This simply produced a pottery-bearing shell midden layer identical to that in J10, between 5 and $18 \mathrm{~cm}$ deep, directly over the same red-brown clay, which occurs beneath the J10 midden. No preceramic occupation whatsoever was identified in the J10 and E12 zones of the cave interior.

Major aspects of the vertical distribution of cultural material in Gua Siti Nafisah are revealed in Table 4.1, which, together with the data from J10 and E12, indicates the following sequence:

1. Layers B, C, D, and the top of E in Squares F5-F8 represent preceramic occupation, with shellfish and marsupial exploitation at a fairly even rate over time, associated with the uses of ochre, small bone points, cooking stones, but absolutely no flaked stone tools. These layers span a period of at least 2500 years, between 5700 and 3000 BP. It is interesting to note that marsupial exploitation was apparently fairly even in intensity through this period; this differs markedly from the situation in the Gebe sites of Wetef and Golo and the Morotai site of Daeo 2, where the vertical distribution of marsupial bone resembles a bell curve with a very definite peak (Chapter 11).

2. In the upper deposits, represented by Layer A in Squares F5-F8 and by the shell middens in J10 and E12, two of the three marsupial species present in the site (the wallaby and bandicoot) continued to be present until about 2500 years ago. Their fates on Halmahera after this date remain unknown. These upper deposits contain pottery (Fig. 7.9), pig bones, two stone adzes (Fig. 8.4), shell ornaments, and even a piece of iron (on J10 surface), and clearly represent a fairly marked cultural change in the history of the site. This occurred despite the absence of any changes in patterns of shellfish exploitation. Two direct C14 dates on pig bones from this phase, both less than $2000 \mathrm{cal}$. BP, are listed in Table 1.1 and discussed in Chapter 10.

3. Occupation in the cave apparently ceased c. $1500 \mathrm{BP}$. 
This text is taken from The Spice Islands in Prehistory: Archaeology in the Northern Moluccas, Indonesia, edited by Peter Bellwood, published 2019 by ANU Press, The Australian National University, Canberra, Australia. 